Abstracta Iranica Abstracta Iranica

Revue bibliographique pour le domaine irano-aryen

Volume 26 | 2005

Comptes rendus des publications de 2003

\title{
« Taḥqīq-e jāme' dar mohmalāt-e fārsī ». Našr $e$ Dāneš, 20, 1 (1382/2003), pp. 49-50.
}

\section{Charles-Henri de Fouchécour}

\section{Q OpenEdition \\ 1 Journals}

Édition électronique

URL : http://journals.openedition.org/abstractairanica/3722

ISSN : 1961-960X

Éditeur :

CNRS (UMR 7528 Mondes iraniens et indiens), Éditions de l'IFRI

Édition imprimée

Date de publication : 15 mai 2005

ISSN : 0240-8910

Référence électronique

Charles-Henri de Fouchécour, « « Tahqīq-e jāme` dar mohmalāt-e fārsī ». Našr-e Dāneš, 20, 1

(1382/2003), pp. 49-50. », Abstracta Iranica [En ligne], Volume 26 | 2005, document 51, mis en ligne le 08 décembre 2005, consulté le 25 septembre 2020. URL : http://journals.openedition.org/

abstractairanica/3722

Ce document a été généré automatiquement le 25 septembre 2020

Tous droits réservés 


\title{
« Taḥqīq-e jāme' dar mohmalāt-e fārsī ». Našr-e Dāně̌, 20, 1 (1382/2003), pp. 49-50.
}

\author{
Charles-Henri de Fouchécour
}

C.r. bien fait de l'ouvrage de Moștafāā D̄ākerī, Atbā' va mohmalāt dar zabān-e fārsī (Našr-e Dānešgāhī-e İrān, 1381/2000, X-209p.), par un excellent bibliophile. Le livre est le fruit de trente ans d'intérêt à ce type de formation des mots comme zād-o valad, darīvarī, etc. Rappel : tābe' - pluriel atba $\bar{a}^{\prime}-$ en annexion : tābe $v a$ mohmal = mot sans signification propre qui suit un autre mot et lui fait écho, comme tāze-māze. Il s'agit d'une enquête très fouillée sur la nature de ce phénomène linguistique persan et arabe, son histoire, ses modèles et la classification de l'ensemble de ses réalisations. Une étude très nouvelle, dont l'A. du c.r. dit aussi les améliorations que devra comporter une nouvelle édition du livre.

\section{INDEX}

Thèmes : 2.2. Langues vivantes et dialectes

Mots-clés : linguistique, langue persane

Keywords : linguistics, Persian language 


\section{AUTEURS}

\section{CHARLES-HENRI DE FOUCHÉCOUR}

Fondateur de la revue Abstracta Iranica - Paris 